\title{
Spacing, population density and nitrogen fertilization in corn grown in an Oxisoil
}

\author{
Maria do Carmo Lana ${ }^{1}$, Leandro Rampim ${ }^{1}$, Tatiane Ohland ${ }^{2}$, Fernando Fávero ${ }^{2}$
}

\begin{abstract}
The objective of this study was to evaluate yield components, leaf nitrogen content and grain yield in corn as affected by row spacing, plant density and nitrogen topdressing. The experiment was conducted with the singlecross hybrid AG 8021, in the municipality of Toledo-PR, in an Oxisoil under no-tillage system, in the crop year 2005/ 2006. The experiment was arranged in a randomized block design and treatments in split-split-plots, with four replications. The two row spacings $(0.45$ and $0.90 \mathrm{~m})$ were allocated in the main plots, the two plant densities $(60,000$ and 80,000 plants ha $\left.{ }^{-1}\right)$ were allocated in the subplots and the three nitrogen rates $\left(80,100,120\right.$ and $\left.140 \mathrm{~kg} \mathrm{ha}^{-1} \mathrm{~N}\right)$ were allocated in the sub-subplots. Topdress nitrogen was applied using urea as $\mathrm{N}$ source. The rise of the plant population from 60,000 to 80,000 plants ha $^{-1}$ and the application of topdress nitrogen resulted in increased production components. The application of topdress fertilization provided increase in leaf $\mathrm{N}$ content and grain yield for the spacings $0.45 \mathrm{~m}$ and $0.90 \mathrm{~m}$. Yield was higher in the spacing $0.45 \mathrm{~m}$ than $0.90 \mathrm{~m}$. Yield was higher with 60,000 plants than with 80,000 plants at $0.90 \mathrm{~m}$, while at $0.45 \mathrm{~m}$ there was no difference in relation to the plant density.
\end{abstract}

Key words: plant arrangement, Zea mays L., urea, topless nitrogen.

\section{RESUMO}

\section{Espaçamento, densidade populacional e adubação nitrogenada na cultura do milho}

O objetivo deste trabalho foi avaliar os componentes de produção, teor de nitrogênio $(\mathrm{N})$ no tecido foliar e produtividade de grãos na cultura do milho em função de diferentes espaçamentos entre linhas, densidade populacional e doses de adubação nitrogenada em cobertura. O experimento foi conduzido no município de ToledoPR, no ano agrícola de 2005/2006, em área de Latossolo Vermelho Eutroférrico sob sistema de semeadura direta, com o híbrido simples AG 8021. O delineamento experimental utilizado foi em blocos casualizados, com quatro repetições e tratamentos dispostos em parcelas subsubdivididas. Nas parcelas foram alocados os espaçamentos entre linhas $(0,45$ e $0,90 \mathrm{~m})$, nas subparcelas foram alocadas as populações de plantas de milho (60 mil e 80 mil plantas ha-1) e nas subsubparcelas foram alocadas as doses de nitrogênio em cobertura (80,100, 120 e $\left.140 \mathrm{~kg} \mathrm{ha}^{-1} \mathrm{de} \mathrm{N}\right)$, utilizando-se

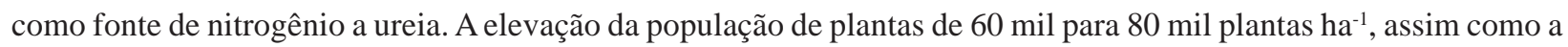
aplicação de doses crescentes da adubação nitrogenada em cobertura proporcionaram incremento nos componentes de produção. A aplicação de $\mathrm{N}$ em cobertura proporciona incremento no teor de $\mathrm{N}$ foliar e na produtividade de grãos para o espaçamento $0,45 \mathrm{~m}$ e $0,90 \mathrm{~m}$. O espaçamento de $0,45 \mathrm{~m}$ alcançou produtividade superior ao espaçamento $0,90 \mathrm{~m}$. Com 60 mil plantas a produtividade foi maior do que com 80 mil plantas no espaçamento de $0,90 \mathrm{~m}$, enquanto que com $0,45 \mathrm{~m}$ não houve diferença quanto à densidade populacional.

Palavras-chave: arranjo de plantas, Zea mays L., ureia, nitrogênio em cobertura.

Recebido para publicação em 08/04/2013 e aprovado em 14/08/2013.

${ }^{1}$ Agronomist, Doctor of Science. Centro de Ciências Agrárias, Universidade Estadual do Oeste do Paraná, Campus Marechal Cândido Rondon, Rua Pernambuco, 1777, Caixa Postal 1008, Centro, 85960-000, Marechal Cândido Rondon, Paraná, Brasil. mariac.lana@ @otmail.com. rampimleandro@yahoo.com.br (corresponding author).

${ }^{2}$ Agronomist, Master of Science. Centro de Ciências Agrárias, Universidade Estadual do Oeste do Paraná, Campus Marechal Cândido Rondon, Rua Pernambuco, 1777, Caixa Postal 1008, Centro, 85960-000, Marechal Cândido Rondon, Paraná, Brasil. 


\section{INTRODUCTION}

The national average corn grain yield in Brazil is around $4400 \mathrm{~kg} \mathrm{ha}^{-1}$ in 2011/2012 (Conab, 2012) and around $5590 \mathrm{~kg}$ $\mathrm{ha}^{-1}$ in the state of Paraná (Seab, 2012). These yields are still far below those in the United States, with average corn yield of $9240 \mathrm{~kg} \mathrm{ha}^{-1}$ (USDA, 2012). Brazilian low yields are closely related to climatic conditions (Cruz et al., 2008; Martin et al., 2011), plant density and plant arrangement (Alvarez et al., 2006; Kaneko et al., 2010; Chioderoli et al., 2012), as well as soil fertility. The average amount of nitrogen $(\mathrm{N})$ used in corn crops in Brazil is $60 \mathrm{~kg} \mathrm{ha}^{-1}$, while in the United States is $150 \mathrm{~kg} \mathrm{ha}^{-1}$ (Coelho, 2007), however, $\mathrm{N}$ is the most limiting nutrient for the growth and development of plants and represents one of the highest input costs in farming systems (Souza et al., 2012).

The spatial arrangement of corn plants varies depending on the spacing between rows and between plants in the row (Von Pinho, 2008; Kappes et al., 2011). Research shows that improving plant arrangement, in equidistant spacings, has contributed to decreasing competition between plants in the row and reducing soil water evaporation due to increased shading (Argenta, 2001). It also facilitates weed management (Trezzi et al., 2008) and provides higher yields (Trezzi et al., 2008; Lana et al., 2009; Modolo et al., 2010). This fact is associated with the use of water, soil nutrients and interception of solar radiation, which are decisive in yield formation (Lauer, 1994; Argenta, 2001; Deparis et al., 2007).

The use of reduced row spacing has provided higher productivity in corn due to more equidistant plant distribution (Von Pinho et al., 2008) coupled to the reduction of the number of plants in the row (Amaral Filho, 2005). The increase in corn yield with reduced spacing identified by Kaneko et al. (2010) and Modolo et al. (2010) facilitates the no-tillage system in crop succession with soybean and corn while maintaining the same spacing for both cultures, without the need to rearrange the seed distribution in seeders.

However, grain yield is also influenced by plant density, with higher yields achieved with densities above 70,000 plants $\mathrm{ha}^{-1}$. This increase is related to the increasing number of ears per area, but excess plant densities lead to competition between plants for water, light and nutrients (Amaral Filho et al., 2005). According to Fancelli and Golden-Neto (2000), well-managed agricultural systems achieve high yields with 55,000 to 72,000 plants ha-1 , using the spacings $0.55 \mathrm{~m}$ and $0.80 \mathrm{~m}$ between rows.

On the other hand, among the nutrients required by crops, nitrogen is the most limiting to growth and yield formation of corn (Raij, 1996). Nitrogen fertilization should consider the expected grain yield and soil organic matter content (Argenta, 2001), since nitrogen interferes positively on yield (Cancellier et al., 2011; Farinelli \& Lemos, 2012) when other factors are not limiting. In southern Brazil (Ceretta, 2000) and in and in the whole country (Coelho, 2007), corn yield is limited by insufficient $\mathrm{N}$ fertilization to the extent that the increase in yield with increasing nitrogen rates is represented by the increase in the number and weight of grains and spike length (Kappes et al., 2011).

Among the various N sources, urea is one of the most used in Brazilian agriculture. Urea has the lowest cost compared to other $\mathrm{N}$ sources and is easily available in the market, but has low use efficiency by crops and high rate of volatilization (Rojas et al. 2012). However, Souza et al. (2011) reported response in corn yield independent of the application mode, before sowing or topdressing with the sources ammonium sulfonitrate with nitrification inhibitor, ammonium sulfate or urea. Similarly, Souza et al. (2012) found that ammonium sulfate and urea enable better economical results.

Thus, the aim of this study was to evaluate the production components, leaf nitrogen content and grain yield in corn for different row spacings, plant densities and nitrogen topdressing.

\section{MATERIALS AND METHODS}

The experiment was conducted in a farm field cultivated under direct seeding system for two years, in the municipality of Toledo - PR, situated between the coordinates 24 34'36' S and 53'48'04' 'W , 480 m altitude, in the agricultural year 2005/2006.

The soil was classified as very clayey Oxisoil (Embrapa, 2006). The 0-0.20 m soil layer was sampled, and a chemical analysis produced the following results: $\mathrm{pH}$ in $\mathrm{CaCl}_{2}=5.4$; O.M. $=20.51 \mathrm{~g} \mathrm{dm}^{-3} ; \mathrm{P}=3.2 \mathrm{mg} \mathrm{dm}^{-3} ; \mathrm{K}=0.67$ $\mathrm{cmol}_{\mathrm{c}} \mathrm{dm}^{-3} ; \mathrm{Ca}=7.68 \mathrm{cmol}_{\mathrm{c}} \mathrm{dm}^{-3} ; \mathrm{Mg}=1.49 \mathrm{cmol}_{\mathrm{c}} \mathrm{dm}^{-3} ; \mathrm{H}$ $+\mathrm{Al}=4.66 \mathrm{cmol}_{\mathrm{c}} \mathrm{dm}^{-3} ; \mathrm{Al}^{3+}=0 \mathrm{cmol}_{\mathrm{c}} \mathrm{dm}^{-3} ; \mathrm{SB}=9.85 \mathrm{cmol}_{\mathrm{c}}$ $\mathrm{dm}^{-3} ; \mathrm{CTC}=14.51 \mathrm{cmol}_{\mathrm{c}} \mathrm{dm}^{-3}$ and $\mathrm{V} \%=68.05$. The rainfall recorded during the experiment was $1151 \mathrm{~mm}$. According to Koppen, the climate is classified as Cfa, subtropical with well distributed rainfall throughout the year and hot summers (Ometto, 1981).

The experiment was arranged in a randomized block design and treatments in split-split-plots, with four replications. The two line spacings $(0.45 \mathrm{~m} 0.90 \mathrm{~m})$ were allocated in the main plots, the two plant densities $(60,000$ and 80,000 plants $\mathrm{ha}^{-1}$ ) were allocated in the subplots and the three nitrogen rates $\left(80,100,120\right.$ and $\left.140 \mathrm{~kg} \mathrm{ha}^{-1} \mathrm{~N}\right)$ were allocated in the sub-subplots.

Each experimental plot was 24 meters long by 8.55 meters wide, in order to keep the same area of $410.40 \mathrm{~m}^{2}$ for each block (measuring $24 \mathrm{~m}$ long x $17.1 \mathrm{~m}$ wide). The spacing between each plot and between each subplot was kept at $0.90 \mathrm{~m}$. The subplots were arranged in nine rows 
with $24 \mathrm{~m}$ in length for the spacing of $0,45 \mathrm{~m}$ and five lines with $24 \mathrm{~m}$ in length for the spacing of $0.90 \mathrm{~m}$, which were divided into four sub-subplots with six $m$ in length. The harvest area for evaluating the sub-subplots consisted of three central lines, excluding $0.50 \mathrm{~m}$ at each end.

The experiment was conducted under direct seeding system in an area that was formerly cultivated with black oat during the winter. Corn sowing was carried out on September 20, 2005, using a tractor mounted seed drill adjusted for the spacings $0.45 \mathrm{~m}$ and $0.90 \mathrm{~m}$ for the plots and sowing depth around $4-5 \mathrm{~cm}$. Seeds of the singlecross hybrid AG 8021, early maturing, tall with semi-hard orange grain were used in the experiment. Plant density was adjusted to 60,000 and 80,000 plants $\mathrm{ha}^{-1}$ in the subplots by thinning after crop emergence. Therefore, 2.7 and 3.6 plants per meter were kept for the densities of 60,000 and 80,000 plants ha ${ }^{-1}$ at the spacing of $0.45 \mathrm{~m}$, while 5.4 and 7.2 plants per meter were kept for the spacing of $0.90 \mathrm{~m}$, respectively.

Basic fertilization was applied with $20 \mathrm{~kg} \mathrm{ha}^{-1} \mathrm{~N}, 30 \mathrm{~kg}$ ha $^{-1} \mathrm{~K}_{2} \mathrm{O}$ and $90 \mathrm{~kg} \mathrm{ha}^{-1} \mathrm{P}_{2} \mathrm{O}_{5}$ at sowing at approximately 12 $\mathrm{cm}$ depth. The sub-subplots were fertilized with four nitrogen rates $\left(80,100,120\right.$ and $\left.140 \mathrm{~kg} \mathrm{ha}^{-1} \mathrm{~N}\right)$ with urea applied when the plants were at the stage of 4-6 fully expanded leaves.

In the tasseling stage, the leaf opposite and below the ear was collected in 10 plants randomly in the harvest area, more precisely, at the time of the appearance of the female inflorescence, in order to determine the nitrogen content in the leaf tissue, according to the methodology established by Malavolta et al. (1997). The collected material was washed with distilled and deionized water and placed to dry in an oven with forced air circulation at 65 ${ }^{\circ} \mathrm{C}$ for 72 hours and then ground in a mill. After sulfuric acid digestion of $0.2 \mathrm{~g}$ samples, total $\mathrm{N}$ was determined by steam distillation in a semi-micro Kjeldahl unit according Tedesco et al. (1995).

Measurements of first ear height (average of the first ear insertion height from ground level in meters) and stem diameter (at ground level in centimeters) were taken during the harvest. Ear harvest was performed manually on January 29, 2006. Ear length, number of rows per ear, number of grains per ear and grain weight per ear were taken from 10 plants randomly chosen in the harvest area of the sub-subplots. The grains were processed in a stationary threshing. The 1000 grain weight was determined from four sub-samples of 100 grains (in grams) taken randomly from the grain harvested to assess yield and corrected to $13 \%$ moisture. Grain yield was based on the yield of each harvest area of the sub-subplots by weighing the grains in a semi-analytical balance and correcting the moisture content to $13 \%$ wet basis, then estimating the yield in $\mathrm{kg} \mathrm{ha}^{-1}$.
Data on nitrogen rates, plant densities and spacings from the experiment were examined by analysis of variance of split-split-plot design and regression adjustment specifically for nitrogen. The models with best fit were based on the significance of the F test for each coefficient of the equations, at $5 \%$ and $1 \%$ probability levels, and the highest coefficient of determination, using the SAEG 8.0 software (SAEG, 1999). Comparison of means of the interaction spacing and plant density was performed by the Tukey test at $5 \%$ probability level. For the single effects of spacing or plant density, it was used the F test, which is conclusive in the case of factors with only two levels.

\section{RESULTS AND DISCUSSION}

The variables of yield components of the corn hybrid AG 8021 were influenced by spacing, plant density and nitrogen $(\mathrm{N})$, with significant interaction among these factors for stem diameter, first ear height, and grain weight per ear. To evaluate these interactions, the effect of spacing, $0.45 \mathrm{~m}$ or $0.90 \mathrm{~m}$, was fixed to analyze the influence of each plant density and $\mathrm{N}$ rates (Table 1 and 2).

Stem diameter was higher in the spacing $0.45 \mathrm{~m}$ than the spacing $0.90 \mathrm{~m}$ (Figure 1a and $1 \mathrm{~b}$ ) value. There was a quadratic effect of $\mathrm{N}$ rates at $0.45 \mathrm{~m}$, showing a quadratic increase with the maximum point at the rate $110.47 \mathrm{~kg}$ of N for the density of 60,000 plants ha ${ }^{-1}$ and maximum point at $122.81 \mathrm{~kg} \mathrm{~N}$ for 80,000 plants ha $^{-1}$. At $0.90 \mathrm{~m}$, there was a linear effect for stem diameter as a function of $\mathrm{N}$ rates for the density of 60,000 plants $\mathrm{ha}^{-1}$ and no effect for the density of 80,000 plants ha $^{-1}$, i.e., no change occurred with increasing $\mathrm{N}$ rates. Therefore, the stem diameter in the spacing $0.90 \mathrm{~m}$ between lines was higher in the density of 60,000 plants ha $^{-1}$ in each $\mathrm{N}$ rate, while the spacing of 0.45 $\mathrm{m}$ with 60,000 plants ha $^{-1}$ was superior only at the rates 80 and $100 \mathrm{~kg} \mathrm{ha}^{-1} \mathrm{~N}$.

The first ear height in the spacing $0.45 \mathrm{~m}$ had linear increase with $\mathrm{N}$ rates for the density of 60,000 plants $\mathrm{ha}^{-1}$ and a quadratic effect for 80,000 plants ha ${ }^{-1}$ with the maximum point at $133.33 \mathrm{~kg} \mathrm{ha}^{-1} \mathrm{~N}$. This result may be related to a nutritional imbalance caused by the $\mathrm{N}$ supply and $\mathrm{S}$ and $\mathrm{Zn}$ deficiency given the demand caused by the increase in yield (Table 1). The density of 60,000 plants ha ${ }^{-1}$ provided higher first ear height in the rates $80 \mathrm{Kg}$ and $140 \mathrm{~kg}$ of $\mathrm{N}$. The spacing $0.90 \mathrm{~m}$ had a quadratic response to the $\mathrm{N}$ rates for the density of 60,000 plants $\mathrm{a}^{-1}$ up to the maximum rate of $125 \mathrm{~kg} \mathrm{ha}^{-1} \mathrm{~N}$, which also may be related to a nutritional imbalance, and a reduction up to the minimum rate of $99 \mathrm{~kg} \mathrm{ha}^{-1} \mathrm{~N}$ for the density of 80,000 plants ha ${ }^{-1}$, i.e., in the density of 60,000 plants $\mathrm{ha}^{-1}$, the first ear height was higher with $120 \mathrm{~kg} \mathrm{~N}$, while in the density of 80,000 plants ha $^{-1}$, it was higher in with $80 \mathrm{~kg} \mathrm{~N}$ (Figures 1c and 1d). 
The reduction in the first ear height in the density of 80,000 plants with increasing amounts of $\mathrm{N}$ may be related to the higher plant growth, and at the same time, a greater demand for other nutrients that become limiting with the increased plant density. Argenta (2001) reported higher plant height and higher first ear height with increase in plant density up to 65,000 plants ha ${ }^{-1}$ and similar result was obtained with $80 \mathrm{~kg} \mathrm{ha}^{-1} \mathrm{~N}$ with the first ear height higher for the density of 80,000 plants $\mathrm{ha}^{-1}$, but from $99 \mathrm{~kg} \mathrm{ha}^{-1}$, the first ear height tended to increase. According Argenta (2001), the reduction in spacing between lines and increase in density can cause changes in plant characteristics due to the higher competition among them.

Grain weight per ear was higher in the spacing $0.45 \mathrm{~m}$ than in $0.90 \mathrm{~m}$ and higher in the density of 60,000 plants ha $^{-1}$ than 80,000 plants ha ${ }^{-1}$ in all $\mathrm{N}$ rates, occurring a linear increase in grain weight per ear for both densities, regardless of the spacing arrangement, $0.45 \mathrm{~m}$ or $0.90 \mathrm{~m}$ (Table 2 and Figures $2 \mathrm{a}$ and $2 \mathrm{~b}$ ).

Number of rows per ear had significant effect only for the use of increasing levels of nitrogen, showing linear increase in this variable with increasing $\mathrm{N}$ rates and there was no difference with the change in spacing and plant density ( Figure 2c).

Ear length was greater in the spacing $0.45 \mathrm{~m}$ than in $0.90 \mathrm{~m}$ (Table 1) and there was a significant interaction between $\mathrm{N}$ rates and plant density (Figure $2 \mathrm{~d}$ ). In this case, both densities 60,000 and 80,000 plants ha ${ }^{-1}$ showed linear increase in ear length with increasing $\mathrm{N}$ rates. This result is consistent with those observed by Kappes et al. (2011). The density of 60,000 plants $\mathrm{ha}^{-1}$ showed higher means than 80,000 plants ha ${ }^{-1}$ in $\mathrm{N}$ rates between 100 and $140 \mathrm{~kg} \mathrm{~N} \mathrm{ha}^{-1}$. According to Fornasieri Filho (1992), the individual corn plant production is maximum in low densities, to the point that the ear is larger and the stem is very strong, making it difficult to mechanized harvesting, however the yield per area is small. In fact, Argenta (2001) found that the density of 50,000 plants ha ${ }^{-1}$ provided a marked increase in ear length.

There was interaction between $\mathrm{N}$ application and plant density for number of grains per ear. At the rates 80 and $120 \mathrm{~kg} \mathrm{~N} \mathrm{ha}^{-1}$, the density of 60,000 plants showed larger number of grains per ear than 80,000 plants (Figure 2e). However, both densities showed a linear increase for number of grains per ear with increasing $\mathrm{N}$ rates, which was also reported by Amaral Filho et al. (2005). Significant interaction was found for this variable between plant density and spacing, since the population of 60,000 plants $\mathrm{ha}^{-1}$ showed a similar number of grains per ear in both spacings of 0.45 and $0.90 \mathrm{~m}$, while the population of 80,000 plants ha ${ }^{-1}$ had higher means in the spacing $0.45 \mathrm{~m}$ (Table 2). In the spacing $0.45 \mathrm{~m}$, the number of grains per ear was similar in both plant densities, whereas in the spacing $0.90 \mathrm{~m}$, the density 60,000 plants $\mathrm{ha}^{-1}$ had higher means. Thus, the increase in plant density also increases competition among plants, resulting in a reduction in the number of grains per ear.

Table 1. Leaf nitrogen content, stem diameter, ear length, grain weight per ear and yield of corn as a function of row spacing, plant density and nitrogen rate in the crop year 2005/2006 in Toledo - PR

\begin{tabular}{|c|c|c|c|c|c|}
\hline \multirow{2}{*}{$\begin{array}{l}\text { Source of } \\
\text { Variation }\end{array}$} & Leaf $\mathbf{N}$ & Stem diameter & Ear length & Grain weight/ear & Yield \\
\hline & $\%$ & \multicolumn{2}{|c|}{$\mathbf{c m}$} & $\mathbf{g}$ & t ha-1 \\
\hline \multicolumn{6}{|l|}{ Factor spacing } \\
\hline $0.45 \mathrm{~m}$ & $2.21 \mathrm{~b}$ & $2.56 \mathrm{a}$ & $17.06 \mathrm{a}$ & $155.88 \mathrm{a}$ & $10.69 \mathrm{a}$ \\
\hline $0.90 \mathrm{~m}$ & $2.29 \mathrm{a}$ & $2.30 \mathrm{~b}$ & $16.75 \mathrm{~b}$ & $140.41 \mathrm{~b}$ & $9.59 \mathrm{~b}$ \\
\hline \multicolumn{6}{|l|}{ Factor density } \\
\hline 60,000 pl. ha- ${ }^{-1}$ & 2.24 & $2.64 \mathrm{a}$ & $17.28 \mathrm{a}$ & $171.17 \mathrm{a}$ & $10.27 \mathrm{a}$ \\
\hline 80,000 pl. ha ${ }^{-1}$ & 2.26 & $2.23 \mathrm{~b}$ & $16.53 \mathrm{~b}$ & $125.13 \mathrm{~b}$ & $10.00 \mathrm{~b}$ \\
\hline \multicolumn{6}{|c|}{ F value } \\
\hline $\mathrm{F} \mathrm{spc}$ & $59.45 * *$ & $71.58 * *$ & $27.76 * *$ & $1252.26 * *$ & $1047.78 * *$ \\
\hline F den & $1.31^{\mathrm{ns}}$ & $95.22 * *$ & $42.68 * *$ & $1281.59 * *$ & $7.57 * *$ \\
\hline $\mathrm{F}$ den $\mathrm{x} \mathrm{spc}$ & 0.01 ns & $35.86 * *$ & $0.02^{\mathrm{ns}}$ & $1.66^{\mathrm{ns}}$ & $8.24 * *$ \\
\hline F Nrate & $128.46 * *$ & $9.12 * *$ & $15.29 * *$ & $143.76 * *$ & $140.80 * *$ \\
\hline F Nrate $\mathrm{x} \mathrm{spc}$ & $8.49 * *$ & $2.55^{\mathrm{ns}}$ & $0.911^{\mathrm{ns}}$ & $2.60^{\mathrm{ns}}$ & $2.20^{\mathrm{ns}}$ \\
\hline F Nrate $\mathrm{x}$ den & $1.37 \mathrm{~ns}$ & $0.82^{\mathrm{ns}}$ & $5.11 *$ & $9.66 * *$ & $2.94 *$ \\
\hline F Nrate $\mathrm{x}$ den $\mathrm{x}$ spc & $0.30^{\mathrm{ns}}$ & $5.77 *$ & $0.55^{\text {ns }}$ & $5.86 * *$ & $5.56 * *$ \\
\hline C.V..$_{\mathrm{spc}}(\%)$ & 1.74 & 5.00 & 1.39 & 1.18 & 1.34 \\
\hline C.V. $\cdot_{\text {den }}(\%)$ & 3.45 & 6.93 & 2.71 & 3.47 & 3.72 \\
\hline C.V. . $_{\text {Nrate }}(\%)$ & 2.76 & 4.31 & 2.07 & 2.22 & 2.22 \\
\hline
\end{tabular}

* and **: significant at $5 \%$ and $1 \%$ level, respectively, by the $\mathrm{F}$ test. ${ }^{\mathrm{ns}}$ non significant at the $5 \%$ level by $\mathrm{F}$ test. Means followed by different letters are significantly different by the $\mathrm{F}$ test at $5 \%$ probability. 
There was a significant interaction between plant density and spacing for 1000 grain weight, since the population of 60,000 plants $\mathrm{ha}^{-1}$ had higher means than 80,000 plants ha-1 for both spacings 0.45 and $0.90 \mathrm{~m}$. Similarly, Amaral Filho et al. (2005), Alvarez et al. (2006), Lana et al. (2009), Modolo et al. (2010) and Mello et al. (2011) also reported reductions in 1000 grain weight with increase in plant density, therefore, the increase in 1000 grain weight may be associated with reduced competition among plants in the density of 60,000 plants ha-1. Interaction between $\mathrm{N}$ application and plant density was also detected, with the density of 60,000 plants showing higher 1000 grain weight (Table 2). For the densities of 60,000 and 80,000 plants ha ${ }^{-1}$ there was increase in 1000 grain weight with increasing rates of $\mathrm{N}$. The density of 60,000 plants ha ${ }^{-1}$ had higher 1000 grain weight in both spacings, 0.45 and $0.90 \mathrm{~m}$. This response indicates a greater effect of competition among plants in density of 80,000 plants ha $^{-1}$ (Figure 2f). The variable 1000 grain weight increased linearly with $\mathrm{N}$ rates in both spacings, which was consistent with the results of Amaral Filho et al. (2005) and Cancellier et al. (2011) who found direct correlation (0.52) between the 1000 grain weight and yield, increasing yield with increasing $\mathrm{N}$ rates.

The results showed that the corn yield components stem diameter, ear length, grain weight per ear, number of grains per ear and 1000 grain weight are negatively affected with the increase in plant population per hectare (Table 1 and 2), which was also reported by Kappes et al. (2011). Similarly, the spacing of $0.90 \mathrm{~m}$ between lines also reflects the effect of competition among plants and negatively affects the same yield components. On the other hand, Stacciarini et al. (2010) found that reducing the spacing from $0.90 \mathrm{~m}$ to $0.45 \mathrm{~m}$ and increasing the density from 60,000 to 90,000 plants ha- ${ }^{-1}$ resulted in higher yield of the hybrid 30K75 without changing ear height, number of grains per ear and 1000 grain weight.

The mean leaf nitrogen content was $2.25 \% \mathrm{~N}$, which is considered below the adequate range (Table 1). According to Raij et al. (1996), for the corn crop, the optimal leaf $\mathrm{N}$ content for a successful development is in the range 2.75 to $3.25 \%$.

There was significant effect for leaf $\mathrm{N}$ content as a function of $\mathrm{N}$ rates independent of plant density, but with different behavior between the spacings and with linear increase up to $140 \mathrm{~kg} \mathrm{~N} \mathrm{ha}^{-1}$ (Figure 3a).

In the spacing of $0.90 \mathrm{~m}$, the corn crop showed higher increase in leaf nitrogen content and yield at the rates 120 and $140 \mathrm{~kg} \mathrm{ha}^{-1}$ of $\mathrm{N}$, probably due to less competition for light among plants. In the spacing of $0.45 \mathrm{~m}$, the leaf $\mathrm{N}$ content was lower than in $0.90 \mathrm{~m}$, thus the higher yield in the spacing $0.45 \mathrm{~m}$ may have caused a diluting effect on leaf $\mathrm{N}$ content, reducing its value (Table 1 and Figure $3 \mathrm{a}$ ). The $\mathrm{N}$ required to produce one

Table 2. First ear height, number of rows per ear, number of grains per ear and of 1000 grain weight of corn as a function of row spacing, plant density per hectare and nitrogen rate in the crop year 2005/2006 in Toledo - PR

\begin{tabular}{|c|c|c|c|c|c|c|}
\hline \multirow{4}{*}{$\begin{array}{l}\text { Source of } \\
\text { Variation }\end{array}$} & \multirow{4}{*}{$\begin{array}{c}\text { First ear } \\
\text { height }\end{array}$} & \multirow{4}{*}{$\begin{array}{c}\text { Number } \\
\text { of rows/ear }\end{array}$} & \multicolumn{2}{|c|}{ Number of grains/ear } & \multicolumn{2}{|c|}{1000 grain weight } \\
\hline & & & \multicolumn{4}{|c|}{ Factor density } \\
\hline & & & \multirow[t]{2}{*}{60,000} & \multirow[t]{2}{*}{80,000} & 60,000 & 80,000 \\
\hline & & & & & \multicolumn{2}{|c|}{ g } \\
\hline \multicolumn{7}{|l|}{ Factor spacing } \\
\hline $0.45 \mathrm{~m}$ & 1.29 & 14.80 & $566 \mathrm{aA}$ & $560 \mathrm{aA}$ & $31 \mathrm{aA}$ & $23 \mathrm{aB}$ \\
\hline $0.90 \mathrm{~m}$ & 1.30 & 14.68 & $568 \mathrm{aA}$ & $527 \mathrm{bB}$ & $28 \mathrm{bA}$ & $22 \mathrm{bB}$ \\
\hline \multicolumn{7}{|l|}{ Factor density } \\
\hline $60,000 \mathrm{pl} \mathrm{ha}^{-1}$ & 1.30 & 14.79 & & & & \\
\hline $80,000 \mathrm{pl} \mathrm{ha}^{-1}$ & 1.29 & 14.69 & & & & \\
\hline \multicolumn{7}{|c|}{ F value } \\
\hline $\mathrm{F} \mathrm{spc}$ & $3.06^{\mathrm{ns}}$ & $1.84^{\mathrm{ns}}$ & \multicolumn{2}{|c|}{$269.52 * *$} & \multicolumn{2}{|c|}{$635.76 * *$} \\
\hline F den & $2.43^{\mathrm{ns}}$ & 0.49 ns & \multicolumn{2}{|c|}{$262.53 * *$} & \multicolumn{2}{|c|}{$1342.81 * *$} \\
\hline$F$ den $x$ spc & 21.84 ns & $1.18^{\mathrm{ns}}$ & \multicolumn{2}{|c|}{$235.97 * *$} & \multicolumn{2}{|c|}{$4.57 *$} \\
\hline F Nrate & $16.61 * *$ & $3.59 *$ & \multicolumn{2}{|c|}{$220.39 * *$} & \multicolumn{2}{|c|}{$60.93 * *$} \\
\hline F Nrate $\mathrm{x}$ spc & $0.45^{\text {ns }}$ & 0.08 ns & \multicolumn{2}{|c|}{$20.86^{\mathrm{ns}}$} & \multicolumn{2}{|c|}{$1.16^{\mathrm{ns}}$} \\
\hline F Nrate $\mathrm{x}$ den & $7.49 * *$ & 0.72 ns & \multicolumn{2}{|c|}{$26.00 *$} & \multicolumn{2}{|c|}{$7.31 * *$} \\
\hline F Nrate $x$ den $x$ spc & $11.41 * *$ & $2.28^{\mathrm{ns}}$ & \multicolumn{2}{|c|}{$22.18^{\mathrm{ns}}$} & \multicolumn{2}{|c|}{$1.62 \mathrm{~ns}$} \\
\hline C.V. $\cdot_{\mathrm{spc}}(\%)$ & 1.11 & 2.44 & \multicolumn{2}{|c|}{20.67} & \multicolumn{2}{|c|}{1.29} \\
\hline C..$_{\text {den }}^{\text {spc }}(\%)$ & 1.49 & 3.99 & \multicolumn{2}{|c|}{22.14} & \multicolumn{2}{|c|}{2.93} \\
\hline C.V. . $_{\text {Nrate }}(\%)$ & 1.71 & 4.71 & \multicolumn{2}{|c|}{21.89} & \multicolumn{2}{|c|}{2.52} \\
\hline
\end{tabular}

$*$ and $* *$ : significant at $5 \%$ and $1 \%$, respectively, ${ }^{\mathrm{ns}}$ non significant at $5 \%$ level by the $\mathrm{F}$ test. Means followed by different capital letters in the row and small letters in the column are significantly different by the Tukey test at $5 \%$ probability. 
tonne of corn grains varies from 27.5 to $32.5 \mathrm{~kg} \mathrm{t}^{-1}$, according Malavolta et al. (1997).

The increase in leaf $\mathrm{N}$ content, according to Souza et al. (2011), increases the grain yield of corn grown after corn up to $150 \mathrm{~kg} \mathrm{ha}^{-1}$ of $\mathrm{N}$, regardless of the application before sowing or topdressing and the source ammonium sulfonitrate with nitrification inhibitor, ammonium sulfate or urea. Amaral Filho et al. (2005) also observed increases in leaf $\mathrm{N}$ content and in estimates of chlorophyll content and yield. Nevertheless, Hurtado et al. (2010) evaluated the nutritional status of corn using a chlorophyll meter and found a need for up to $180 \mathrm{~kg} \mathrm{ha}^{-1} \mathrm{~N}$, exceeding the amount required to achieve maximum yield with $150 \mathrm{~kg} \mathrm{ha}^{-1}$ (Souza et al., 2011).

In high fertile soils, such as the Oxisoil of this study, there is a stronger correlation between $\mathrm{N}$ content in the corn plant and grain yield (Rambo et al., 2011). Fontoura and Bayer (2009) discussed that the determination of the $\mathrm{N}$ rate to achieve maximum economic efficiency for corn is related to the $\mathrm{N}$ demand for the different ranges of crop yield, the soil $\mathrm{N}$ supply capacity by the organic matter, the effect of the predecessor cover crop on the $\mathrm{N}$ availability and efficiency of applied $\mathrm{N}$ via mineral fertilizer.
Even with the linear increase in yield detected in this study, it is important to apply nitrogen fertilizer rationally for each farm. Farinelli \& Lemos (2012) stated that topdress $\mathrm{N}$ promotes significant increase in agronomic and nutritional characteristics of corn, reaching maximum grain yield with $151 \mathrm{~kg} \mathrm{ha}^{-1}$ of $\mathrm{N}$. However, the rate of $90 \mathrm{~kg} \mathrm{ha}^{-1} \mathrm{~N}$ can be used for mediumtechnology farmers as it provides $20 \%$ of agronomic efficiency and can reach yield of $8.50 \mathrm{t} \mathrm{ha}^{-1}$ of grains and high-technology farmers can use $150 \mathrm{~kg} \mathrm{ha}^{-1}$, which provides $12 \%$ of agronomic efficiency and reaches yield of $8.90 \mathrm{~kg} \mathrm{ha}^{-1}$.

For grain yield, there was a significant interaction among the effects of spacing, density and nitrogen rates, therefore the effect of spacing $0.45 \mathrm{~m}$ or $0.90 \mathrm{~m}$ was fixed to analyze the influence of each density and nitrogen rate on the variable (Table 1 and Figures $3 \mathrm{~b}$ and $3 \mathrm{c}$ ).

In the spacing $0.45 \mathrm{~m}$, the grain yield response to $\mathrm{N}$ fertilization was independent of the plant density used, ie, there was no significant difference in yield between the populations at the rates evaluated, which indicates that the competition among plants in the line and between lines was weak in this condition (Figure 3b). However, in
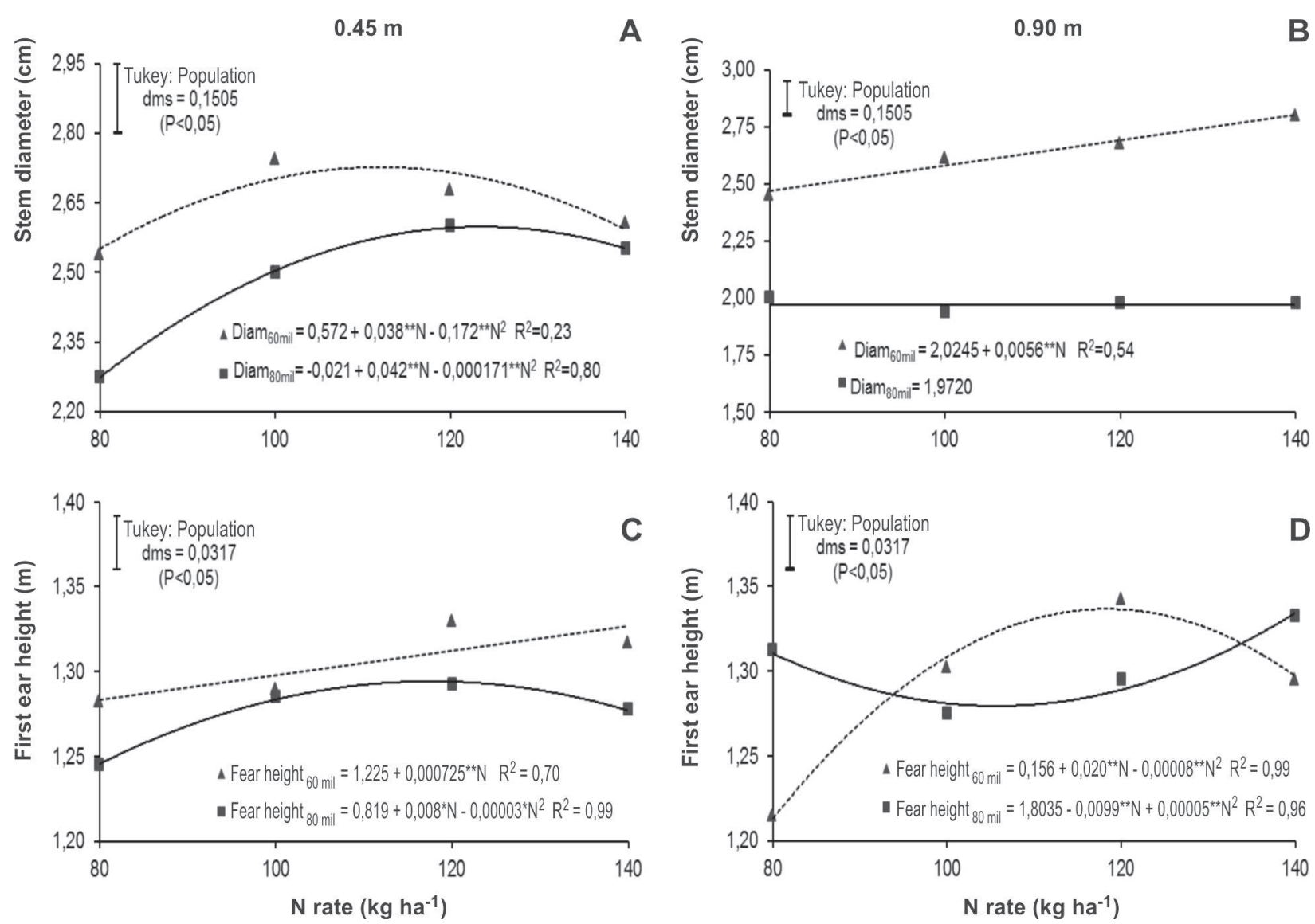

Figure 1. Stem diameter (a) and first ear height (c) in the spacing between lines of $0.45 \mathrm{~m}$, stem diameter (b) and first ear height (d) in the spacing between lines of $0.90 \mathrm{~m}$ for each plant density and as a function of nitrogen rates in the corn crop in the crop year 2005/ 2006 in Toledo - PR. * and **: significant at 5 and $1 \%$ by the $\mathrm{F}$ test. 
the spacing of $0.90 \mathrm{~m}$, with the increase in density from 60,000 to 80,000 plants $\mathrm{ha}^{-1}$, the competition among plants was more intense, leading to lower yield, especially at the rates of 120 and $140 \mathrm{~kg} \mathrm{~N}$ for the density of 80,000 plants $\mathrm{ha}^{-1}$ (Figure 3c). In this spacing, competition among plants in the line was higher and the increase in corn yield provided for each $\mathrm{kg}$ of $\mathrm{N}$ added was only $19.1 \mathrm{~kg}$ of grain for 80,000 plants $\mathrm{ha}^{-1}$, while for 60,000 plants ha-1 ${ }^{-1}$ the increase in yield was $33.3 \mathrm{~kg}$ grain per $\mathrm{kg}$ of $\mathrm{N}$ added, with a greater response to fertilization (Figure 3c). Fancelli and Dourado-Neto (2000) discussed that a high plant density can cause premature shading of
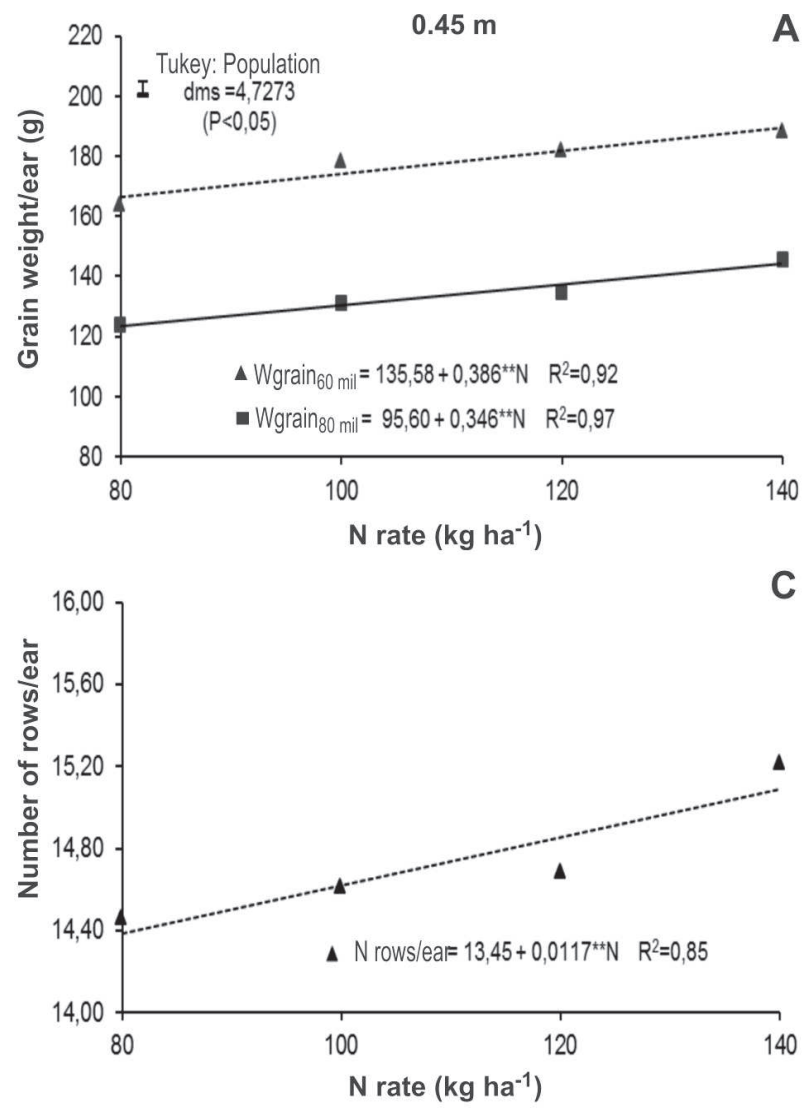

C

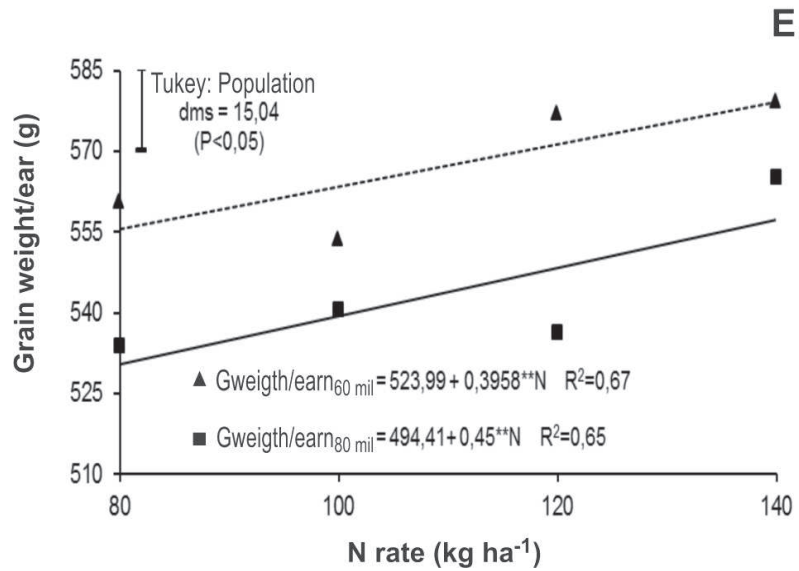

leaves and reduce leaf area index, reducing the potential for plant production. Our results are consistent with Brachtvogel et al. (2009), who found increase in grain yield from 30,000 to 70,000 plants $\mathrm{ha}^{-1}$ and decrease in 90,000 plants $\mathrm{ha}^{-1}$, regardless of the spacing, with maximum yield in the spacing of $0.80 \mathrm{~m}$ and density of 67,000 plants ha ${ }^{-1}$. On the other hand, Von Pinho et al. (2008) achieved maximum grain yield with 85,000 plants ha $^{-1}$ and Alvarez et al. (2006) observed higher grain yield with increasing rates of topdress nitrogen in association with $0.80 \mathrm{~m}$ between lines and 80,000 plants ha- ${ }^{-1}$. Moreover, Melo et al. (2011) observed maximum corn
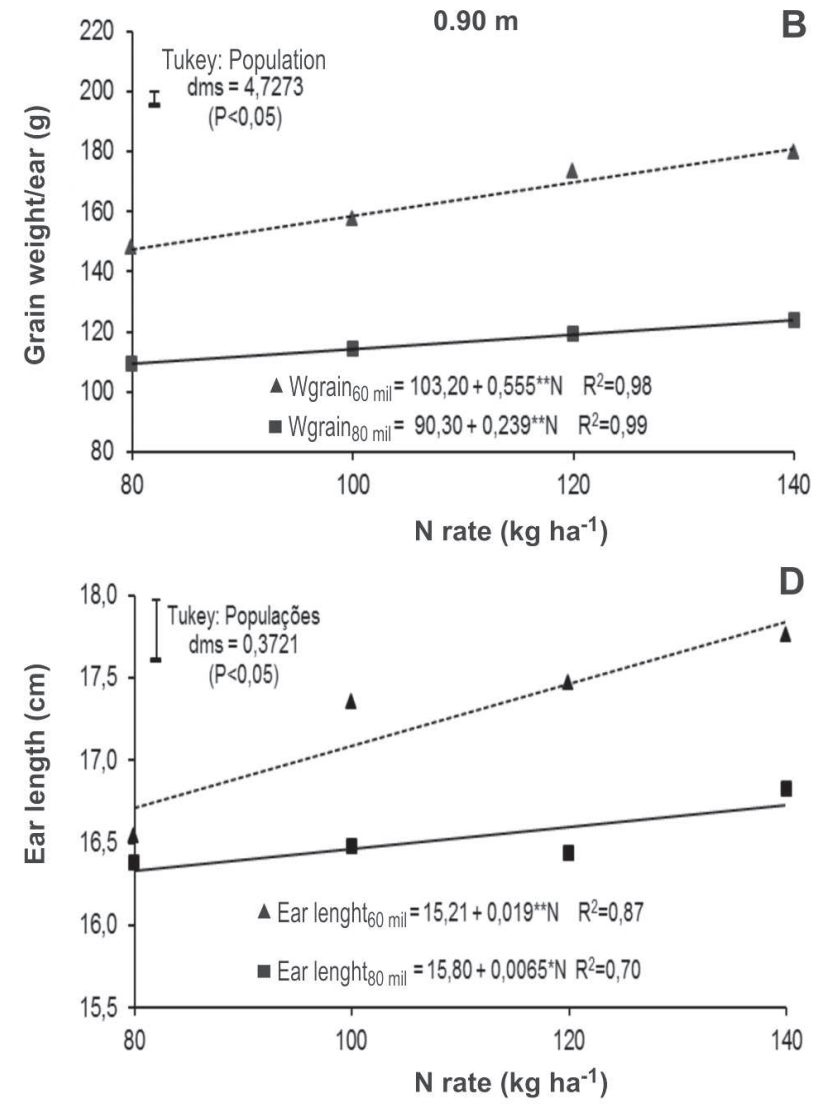

E

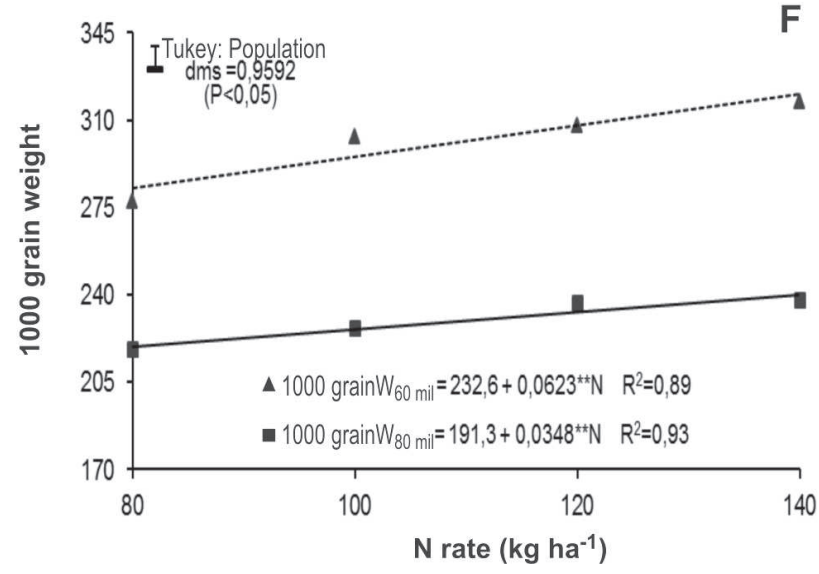

Figure 2. Grain weight per ear in the spacing between lines of $0.45 \mathrm{~m}$ (a) and grain weight per ear in the spacing between lines of 0.90 $\mathrm{m}$ (b), number of rows per ear (c), ear length (d), number of grains per ear (e) and 1000 grain weight (f) in the corn crop for each plant density as a function of nitrogen rates in the crop year 2005/2006 in Toledo - PR. * and **: significant at 5 and $1 \%$ by the $\mathrm{F}$ test.

Rev. Ceres, Viçosa, v. 61, n.3, p. 424-433, mai/jun, 2014 
grain yield with $120 \mathrm{~kg} \mathrm{ha}^{-1} \mathrm{~N}$ and density of 80,000 plants $\mathrm{ha}^{-1}$, whereas higher $\mathrm{N}$ rates lead to luxury consumption by the plant as it increases the concentration of $\mathrm{N}$ in the shoot and decreases grain yield.

By fixing the spacing effect, it was possible to observe that the average yield of the spacing $0.45 \mathrm{~m}$ (10.69 $\left.\mathrm{t} \mathrm{ha}^{-1}\right)$ was significantly higher than the spacing $0.90 \mathrm{~m}$ (9.59 $\mathrm{t} \mathrm{ha}^{-1}$ ) ( Table 1), which was also confirmed by Von Pinho et al. (2008) with different corn hybrids. These authors observed that the spacing $0.45 \mathrm{~m}$ yielded $6.67 \mathrm{t} \mathrm{ha}^{-1}$ of grains, while $0.90 \mathrm{~m}$ yielded $5.81 \mathrm{t} \mathrm{ha}^{-1}$, occurring more equidistant plant distribution in the area with the hybrids $30 \mathrm{~K} 75$ and Tork in the spacing $0.45 \mathrm{~m}$. Similarly, Argenta (2001) and Kaneko et al. (2010) obtained increased yield by reducing the row spacing from 0.90 to $0.45 \mathrm{~m}$.

Reduction in row spacing allows better distribution of plants in the area and less inter and intraspecific competition for nutrients, water, light and other factors (Amaral Filho et al., 2005; Deparis et al., 2007), providing highest grain yields. However, the spacing did not affect the corn grain yield in a study recently done by Sangoi et al. (2011), because according to Argenta et al. (2001) and Strieder et al. (2008) the effects of this cultural practice depend on the hybrid and the level of technology used.

It is important to consider the different performances among genotypes reported in other studies and evidenced by Kappes et al. (2011), in which the change in spacing to $0.45 \mathrm{~m}$ influenced the grain yield of the hybrid AG 9010 increasing the yield in $15 \%$, especially for the density of 90,000 plants $\mathrm{ha}^{-1}$. The highest yield was obtained with the hybrid XB 7253 with 70,000 plants ha ${ }^{-1}$ in the spacings of 0.45 and $0.90 \mathrm{~m}$, while for the hybrids XB 6010, XB 6012 and XB 9003 there was no significant response to spatial arrangements and 50,000 plants $\mathrm{ha}^{-1}$ could be recommended for both spacings. In another study, Trezzi et al. (2008) found higher yield with the hybrid Penta in the spacing $0.90 \mathrm{~m}$, while the hybrid Sprint had similar yield in both spacings $0.90 \mathrm{~m}$ and $0.45 \mathrm{~m}$.

Thus, the farmer who aims to achieve higher yields in corn, first, should invest on high nitrogen fertilization and prioritize the adequate plant density for each genotype. However, the increase in $\mathrm{N}$ rates requires the split of nitrogen fertilization to enhance the increase in yield (Von Pinho et al., 2008).
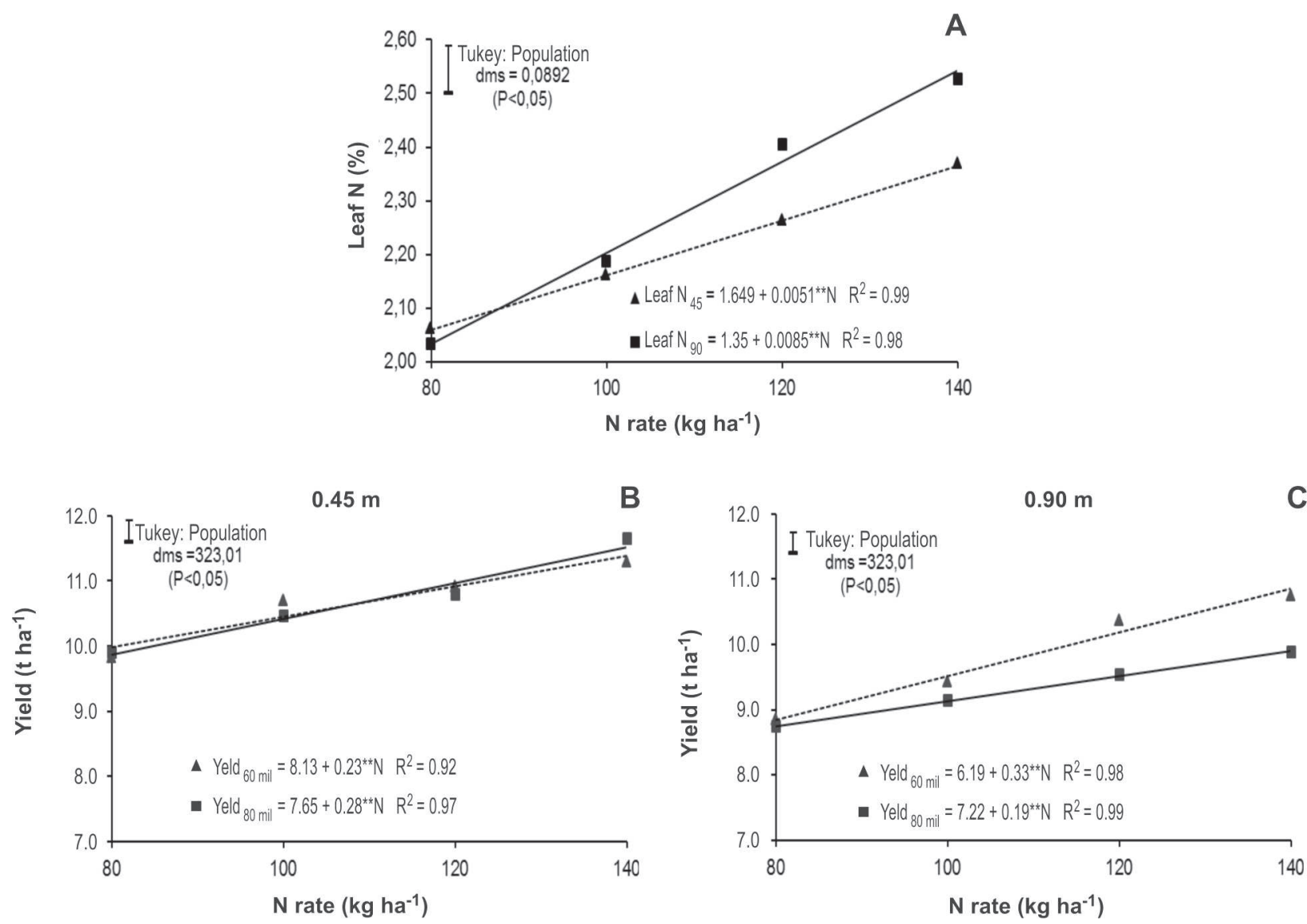

Figure 3. Leaf $\mathrm{N}$ content for the spacings 0.45 and $0.90 \mathrm{~m}$ as a function of nitrogen rates (a), yield in the spacing of $0.45 \mathrm{~m}$ (b) and yield in the spacing of $0.90 \mathrm{~m}$ (c) for each plant density and as a function of nitrogen rates in corn in the crop year 2005/2006 in Toledo - PR. * and **: significant at 5 and $1 \%$ by the $\mathrm{F}$ test. 
The use of higher nitrogen rates, adequate plant density and sowing speed may increase the corn yield without changing the spacing between lines (Alvarez et al., 2006; Trezzi et al., 2008; Alvarez et al., 2009; Kappes et al., 2011; Sangoi et al., 2011). The reduction in spacing requires suitable platforms for harvesting, therefore the farmer needs to modify or acquire new platforms to harvest in reduced spacings (Dias et al., 2009), which results in increased costs. However, it is pertinent to reduce spacing between lines in areas that exceed the grain yield of $10 \mathrm{t}$ ha $^{-1}$ (Strieder et al., 2008), as it occurred in this study.

\section{CONCLUSIONS}

The corn yield components (stem diameter, ear length, grain weight per ear, number of grains per ear and 1000 grain weight) were negatively affected by the increase in plant density from 60,000 to 80,000 plants per hectare.

The application of increasing nitrogen rates provided increase in leaf $\mathrm{N}$ content, stem diameter, first ear height, ear length, number of rows per ear, number of grains per ear, grain weight per ear, 1000 grain weight and grain yield.

The hybrid AG 8021 had higher yield in the line spacing of $0.45 \mathrm{~m}$ than in the line spacing of $0.90 \mathrm{~m}$.

In the line spacing of $0.45 \mathrm{~m}$, grain yield was similar for both densities of 60,000 and 80,000 plants ha-1.

In the line spacing of $0.90 \mathrm{~m}$, grain yield was higher for the density of 60,000 plants ha-1.

\section{REFERENCES}

Alvarez CGD, Von Pinho RG \& Borges ID (2006) Avaliação de características agronômicas e de produção de forragem e grãos de milho em diferentes densidades de semeadura e espaçamentos entre linhas. Ciência e Agrotecnologia, 36:402-408.

Alvarez CGD, Von Pinho RG, Borges ID, Dias VO, Alonço AS, Baumhardt UB \& Bonotto GJ (2009) Distribuição de sementes de milho e soja em função da velocidade e densidade de semeadura. Ciência Rural, 39:1721-1728.

Amaral Filho JPR, Fornasieri Filho D, Farinelli R \& Barbos JC (2005) Espaçamento, densidade populacional e adubação nitrogenada na cultura do milho. Revista Brasileira de Ciência do Solo, 29:467-473.

Argenta G (2001) Arranjo de plantas em milho: análise do estadoda-arte. Ciência Rural, 31:1075-1084.

Brachtvogel EL, Pereira FR, Cruz SCS \& Bicudo SJ (2009) Densidades populacionais de milho em arranjos espaciais convencional e eqüidistante entre plantas. Ciência Rural, 39:2334-2339.

Cancellier LL, Afférri FS, Carvalho EV, Dotto MA \& Leão FF (2011) Eficiência no uso de nitrogênio e correlação fenotípica em populações tropicais de milho no Tocantins. Revista Ciência Agronômica, 42:139-148.

Ceretta CA (2000) Dinâmica do nitrogênio em sistemas de produção na região Sul do Brasil. Dourados, Embrapa Agropecuária Oeste. Seropédica, Embrapa Agrobiologia. 163p. (Documentos, 28).
Chioderoli CA, Mello LMM, Grigolli PJ, Furlani CEA, Silva JOR \& Cesarin AL (2012) Atributos físicos do solo e produtividade de soja em sistema de consórcio milho e braquiária. Revista Brasileira de Engenharia Agrícola e Ambiental, 16:37-43.

Coelho AM (2007) Manejo da adubação nitrogenada na cultura do milho. Sete Lagoas, Embrapa Milho e Sorgo. 11p. (Circular técnica, 96.)

Conab - Companhia Nacional de Abastecimento. Acompanhamento da safra Brasileira: grãos, oitavo levantamento junho 2012/ Companhia Nacional de Abastecimento, Brasília: Conab, 2012. Disponível em: <http://www.conab.gov.br/OlalaCMS/ uploads/arquivos/ 12_0_05_09_50_17_boletim_safra_-_junho2012.pdf>. Acesso em 05 de junho de 2012.

Cruz SCS, Pereira FRS, Santos JR, Albuquerque AW \& Pereira RG (2008) Adubação nitrogenada para o milho cultivado em sistema plantio direto, no Estado de Alagoas. Revista Brasileira de Engenharia Agrícola e Ambiental, 12:62-68.

Deparis GA, Lana MC \& Frandoloso JF (2007) Espaçamento e adubação nitrogenada e potássica em cobertura na cultura do milho. Acta Scientiarum Agronomy, 29:517-525.

Dias VO, Ferri DJ, Alonço AD \& Souza, R.S. (2009) Análise de investimento em plataformas colhedoras de milho em espaçamento reduzido: efeito de oscilações da produtividade, do preço do milho e da semente. Engenharia Agrícola, 29:249-256.

Embrapa - Empresa Brasileira de Pesquisa Agropecuária (2006) Sistema brasileiro de classificação de solos. Brasília, Embrapa Produção de Informação. 306p.

Fancelli AL \& Dourado-Neto D (2000) Produção de milho. Guaíba, Agropecuária. 360p.

Farinelli R \& Lemos LB (2012) Nitrogênio em cobertura na cultura do milho em preparo convencional e plantio direto consolidados. Pesquisa Agropecuária Tropical, 42:63-70.

Fontoura SMV \& Bayer C (2009) Adubação nitrogenada para alto rendimento de milho em plantio direto na região centro-sul do Paraná. Revista Brasileira de Ciência do Solo, 33:721-1732.

Fornasieri Filho D (1992) A cultura do milho. Jaboticabal, Funep. 273 p.

Hurtado SMC, Silva CA, Resende AV, Corazza EJ, Shiratsuchi LS \& Higashikawa FS (2010) Sensibilidade do clorofilômetro para diagnóstico nutricional de nitrogênio no milho. Ciência e Agrotecnologia, 34:688-697.

Kaneko FH, Arf O, Gitti DC, Arf MV, Chioderoli CA \& Kappes C (2010) Manejo do solo e do nitrogênio e milho cultivado em espaçamentos reduzidos e tradicional. Bragantia, 69:677-686.

Kappes C, Andrade JA, Arf O, Oliveira AC, Arf MV \& Ferreira JP (2011) Desempenho de híbridos de milho em diferentes arranjos espaciais de plantas. Bragantia, 70:334-343.

Lana MC, Junior PPW, Bracicini AL, Scapim CA, Ávila MR \& Albrecht LP (2009) Arranjo espacial e adubação nitrogenada em cobertura na cultura do milho. Acta Scientiarum Agronomy, 31:433-438.

Laüer J (1994) Should 1 be planting corn at a 30-inch row spacing? Wisconsin Crop Manager, 1:6-8.

Malavolta E, Vitti GC \& Oliveira AS (1997) Avaliação do estado nutricional das plantas: princípios e aplicações. $2^{\mathrm{a}}$ ed. Piracicaba, Associação Brasileira para a pesquisa da Potassa e do Fosfato. $319 \mathrm{p}$.

Martin TN, Venturini T, Api I, Pagnoncelli A \& Vieira Júnior PA (2011) Perfil do manejo da cultura de milho no sudoeste do Paraná. Revista Ceres, 58:01-08. 
Melo FB, Corá JE \& Cardoso MJ (2011) Fertilização nitrogenada, densidade de plantas e rendimento de milho cultivado no sistema plantio direto. Revista Ciência Agronômica, 42:27-31.

Modolo AJ, Carnieletto R, Kolling EM, Trogello E \& Sgarbossa M (2010) Desempenho de híbridos de milho na Região Sudoeste do Paraná sob diferentes espaçamentos entre linhas. Revista Ciência Agronômica, 41:435-441.

Ometto JC (1981) Bioclimatologia vegetal. São Paulo, Agronômica Ceres Ltda. 440p.

Raij Bvan, Cantarella H, Quaggio JA \& Furlani AMC (1996) Recomendações de adubação e calagem para o estado de São Paulo. $2^{\mathrm{a}}$ ed. Campinas, Instituto Agronômico de Campinas. p.60-61. (Boletim, 100).

Rambo L, Silva PRF, Strieder ML, Silva AA, Sangoi L \& Vieira VM (2011) Índices nutricionais de $\mathrm{N}$ e produtividade de milho em diferentes níveis de manejo e de adubação nitrogenada. Pesquisa Agropecuária Brasileira, 46:390-397.

Rojas CAL, Bayer C, Fontoura AMV, Weber MA \& Vieiro F (2012) Volatilização de amônia da ureia alterada por sistemas de preparo de solo e plantas de cobertura invernais no Centro-Sul do Paraná. Revista Brasileira de Ciências do Solo, 36:261-270.

SAEG (1999) Sistema para análises estatísticas. Versão 8.0. Viçosa, Universidade Federal de Viçosa. CD-ROM.

Sangoi L, Schweitzer C, Silva PRF, Schmitt A, Vargas VP \& Casa RT (2011) Perfilhamento, área foliar e produtividade do milho sob diferentes arranjos espaciais. Pesquisa Agropecuária Brasileira, 46:609-616.

SEAB (2012) Secretaria do Estado de Agricultura e Abastecimento do Paraná, Estimativa de safra, maio 2012, Curitiba, PR. Disponível em: < www.seab.pr.gov.br/>. Acessado em 05 de junho de 2012 .

Souza JA, Buzetti S, Teixeira Filho MCM, Andreotti M, Sá ME \& Arf O (2011) Adubação nitrogenada na cultura do milho safrinha irrigado em plantio direto. Bragantia, 70:447-454.
Souza JA, Buzetti S, Tarsitan O, Ma A \& Valderrama M. (2012) Lucratividade do milho em razão das fontes, doses e épocas de aplicação de nitrogênio. Revista Ceres, 59:321-329.

Stacciarini TCV, Castro PHC, Borges MA, Guerin HF, Moraes PAC \& Gotardo M (2010) Avaliação de caracteres agronômicos da cultura do milho mediante a redução do espaçamento entre linhas e aumento da densidade populacional. Revista Ceres, 57:516-519.

Strieder ML, Silva PRF, Rambo L, Bergamaschi H, Dalmago GA, Endrigo PC \& Jandrey DB (2008) Características de dossel e rendimento de milho em diferentes espaçamentos e sistemas de manejo. Pesquisa Agropecuária Brasileira, 43:309-317.

Tedesco MJ, Wolkweiss SJ \& Bohnen H (1995) Análises de solo, plantas e outros materiais. Porto Alegre, UFRGS. 188p. (Boletim técnico, 5).

Trezzi MM, Vidal RA, Kruse ND, Prates MVB, Gustman MS, Nunes AL \& Argenta G (2008) Manejo químico de plantas daninhas na cultura do milho em função de características morfofisiológicas e redução de espaçamento da cultura. Planta Daninha, 26:845-853.

Usda (2012) States Department of Agriculture, by the National Agricultural Statistics Service (NASS), Agricultural Statistics Board, Crop production, publicado em 10 de maio de 2012. Disponível em: <http://usda01.library.cornell.edu/usda/current/ CropProd/CropProd-05-10-2012.pdf >. Acessado em 05 de junho de 2012.

Von Pinho RG, Gross MR, Steola AG \& Mendes MC (2008) Adubação nitrogenada, densidade e espaçamento de híbridos de milho em sistema plantio direto na região sudeste do Tocantins. Bragantia, 67:733-739. 